The small staff of the Nutrition Laboratory has been engaged in important war research in cooperation with groups at the Harvard Medical School. Projects under the Division of Historical Research have been of interest in supplementing the Government's programme of inter-American cultural relations. The knowledge possessed by the staff members of this Division with regard to geographical and economic conditions in Central America is also proving of assistance in connexion with the Government's war programme.

\section{ACID NEUTRALIZATION IN INSULATING PAPERS}

$\mathrm{TN}$ the manufacture of paper-insulated condensers, impregnating materials are used to eliminate air pockets and to increase the dielectric capacity of the paper. With long use, particularly at high temperatures and under high voltages, traces of hydrochloric acid are liberated from chlorinated impregnants. The acid, and the salts formed by its reaction with the metal electrodes, ultimately decompose the paper and break down the condenser. . This destruction is delayed by calcium, magnesium and other metals combined chemically with the paper which neutralize the hydrochloric acid.

An article by D. A. MeLean (Bell Lab. Rec., 21, No. 6 ; Feb. 1943) gives some of the results of an investigation carried out on the properties of Kraft and linen papers. Exchange reactions in cellulose materials do not take place in the principal constituent but in other organic materials with which cellulose is always associated, including lignin, pectic substances and pentosans. Differences in content of these minor components explain why papers differ so greatly in exchange capacity. Kraft paper, which is much superior to linen for condenser insulation, has several times the exchange capacity of linen tissue. In apparatus with which accelerated lifetests of condenser papers are carried out, condensers are heated in an oil bath and a continuous record made of the leakage current until the paper under test breaks down.

When aluminium electrodes are used in condensers made with paper impregnated with chlorinated compounds, decomposition of the dielectric proceeds from central nuclei about which the paper becomes partially carbonized. If the sample is dismantled after accelerated tests at high temperature and with D.c. voltage, these areas can be seen as brown spots. Under ordinary artificial light a photograph shows dark spots on a light background, but with ultraviolet light the spots fluoresce brightly.

Papers of high exchange capacity are capable of suppressing the formation of decomposed areas, and in two samples taken from a condenser after approximately equal periods of test at the same voltage, linen paper is shown to become thickly populated. with decomposed areas which have grown from minute centres seen scattered through the sample, whereas Kraft paper shows only slight evidence of decomposition. More severe conditions of test are required to produce serious deterioration in the Kraft paper.

Superiority of Kraft paper as a dielectric is illus. trated by comparing the energy losses at elevated temperatures in condensers made with this material and with linen. The lower power factor in Kraft paper is due to the binding of ionic material by its base exchange properties, which decreases the A.c. losses. Values given in the article were determined at low potential gradients, under which conditions ionization is most readily detected by A.C. measurements. Condenser papers of high exehange capacity reduce leakage current, and typical results obtained with linen paper under accelerated test conditions show a rapid increase of leakage and dielectric failure after 40 hours. In contrast, Kraft paper has a much more stable leakage eurrent and a life of 350 hours, as its high base exchange capacity suppresses decomposition. These studies of exchange reactions in condenser papers impregnated with chlorinated compounds have led to the development of stabilizers which extend the life of condensers, under stated severe test conditions, to several thousand hours.

\section{APPOINTMENTS VACANT}

Applications are invited for the following appointments on or before the dates mentioned:

HeAd OF THE ElECtrical ENGINEERING DEPARTMENT-The Registrar, Technical College, Sunderland (August 6).

LECTURER (MAN OR 'WOMAN) IN CHEMISTRY in the Croydon Polytechnic-The Education Officer, Education Office, Katharine Street, Croydon (August 6).

SPEECH THERAPIST (full-time)-The Secretary for Education, SPEECH THERAPIST (full-time)
Education Offices, York (August 6).

Graduate assistant Master to teach EnginenRing DRawing in the Middlesbrough Technical School for Boys-The Director of Education, Education Offices, Middlesbrough (August 7).

TEACHER OF MINING SUBJECTs in the Denbighshire Technical College, Wrexham-The Director of Education, Education Offices, Ruthin (August 7).

ASSISTANT MASTHR (preferably a Graduate with works experience) to teach TECHNICAL DRAWING AND MATHEMATICS in the Sunderland Offices, Carlton House, Mowbray Road, Sunderland (August 9).

Assistant to teach MATHEMatics and other Junior Engineering Subjects - The Principal, County Technical College and. School of Art, Newark, Notts. (August 9).

LECTURER IN Mathematics in the Constantine Technical College, Middlesbrough-The Director of Education, Education Offices, Middlesbrough (August 14).

Head of the Department of ChILD Development in succession to Dr. Susan Isaacs-The Secretary, University of London Institute of Education, at. University College, Nottingham (August 14).

LECTURER (TEMPORARY) IN PHYsICs-The Acting Secretary of University Court, 'The University, Glasgow (August 15).

assistant Lecturer and Demonstrator in the Physiology DEPARTMENT-The Secretary, The University, Birmingham (August 18).

LECTURER (TEMPORARY) IN CHEMISTRY-The Registrar, University College, Southampton (August 25).

Professor of Physiology, a Senior Lecturer in ANatomy, and A SENIOR LEC'TURER IN PHYSIOLOGY, in the University of Otago, Dunedin-The High Commissioner for New Zealand, 415 Strand; London, W.C.2 (August 31).

CHEMIST AND ASSAYER on the establishment of the South African Mint, Pretoria-The Secretary, Office of the High Commissioner for the Union of South Africa, South Africa House, Trafalgar Square, London, W.C.2 (August 31).

Heads of The Departments of Physiology, Medicine, and SURGERY-The Bursar, Royal Veterinary College and Hospital, at The University, Reading (October 1).

CHAIR OF NAVAL ARCHITECTURE-The Acting Secretary of University Court, The University, Glasgow (October 4).

ENGINEERINA WORKSHOP INSTRUCTOR for service in the Bury Junior Technical School and Bury Municipal Technical College (Even ing Classes)-The Director of Education, Education Offices, Bury.

\section{REPORTS and other PUBLICATIONS (not included in the monthly Bools Supploment)} Great Britain and Ireland

Young Workers and their Education: Providing the Kight Type of Education and Problems of Release from Work. A Report of a Conference held at the College of Technology, Manchester, April 15th 1943 , under the auspices of the British Association for Commercia and Industrial Education. Pp. 40. (London: British Association for Commercial and Industrial Education.) 1s. Brish Association

Geological Survey of Great Britain: England and Wales. Wartime Pamphlet No. 33: Glauconite Sand of Bracklesham Beds, London Basin. By Dr. Kenneth P. Od. Pakley. Pp. 28. (London: Geological
[167 